\title{
Subdelegados en Aguascalientes a fines del siglo XVIII. La aplicación de la Ordenanza de Intendentes
}

FRANCISCO JAVIER DELGADO AGUILAR

Instituto Mora

RESUMEN

Cl artículo hace un análisis de la aplicación de la Ordenanza de Intendentes de 1786 en la villa de Aguascalientes, ocupándose principalmente del papel y la función que desempeñaron los subdelegados y su posición en la cadena de mando formada por ayuntamientos e intendentes. Tomando en cuenta tanto los ordenamientos legales como las fuerzas políticas predominantes, el artículo muestra mediante un estudio de caso los problemas y límites a los que se enfrentaron los reformistas borbónicos en su intento por modificar las estructuras de poder locales.

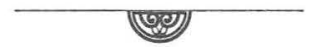

\begin{abstract}
"SUBDELEGADOS" IN AGUASCALIENTES AT THE END OF THE EIGHTEENTH CENTURY.

THE APLICATION OF THE ORDENANZAS DE INTENDENTES

This article analizes the aplication of the Ordenanzas de Intendentes (1786) in the village of Aguascalientes, through the role of "Subdelegados" in the power structure formed by City Councils ("Ayuntamientos") and "Intendentes". Taking into account not only the Ordenanzas but the main political actors, this article shows some problems and limits that the Borbonic reforms faced in their trial to modify the local power.
\end{abstract}




\section{INTRODUCCIÓN}

objetivo del presente trabajo es hacer un análisis del papel del subdelegado en la cadena de mando establecida en el nivel provincial por la Ordenanza de Intendentes de 1786. Dicha cadena -conformada por la relación entre Intendente, subdelegados y ayuntamientos- fue una de las principales innovaciones implementadas durante la época y de su funcionamiento adecuado dependía en buena medida el éxito de dicha Ordenanza.

Para lograr lo anterior hemos dividido el trabajo en tres partes; en la primera hacemos una rápida descripción de la estructura de gobierno local existente hasta antes de 1786 y mencionamos la evolución que tuvo el reformismo borbónico, conjunto de medidas político-administrativas que tenían por objetivo modificar dicha estructura de gobierno; lo primero nos sirve para ver cuáles fueron las modificaciones introducidas por la nueva legislación y los principales aspectos que se querían modificar, mientras que lo segundo tiene el objetivo de ubicar en un contexto más específico la expedición de la Ordenanza y su significado dentro del conjunto de cambios introducidos en esta época. La segunda parte consiste en el análisis propio de la Ordenanza, tomando en cuenta las atribuciones del intendente, el subdelegado y el ayuntamiento, las relaciones que éstos establecían entre sí y con otras autoridades y las posteriores reformas que sufrió dicho ordenamiento. Finalmente, la tercera parte presenta un estudio de caso de la subdelegación de Aguascalientes que sirve para ilustrar de manera concreta el funcionamiento real del gobierno distrital y la cadena de mando ya mencionada. ${ }^{1}$

\footnotetext{
${ }^{1}$ Conviene mencionar que al finalizar la investigación para el presente artículo tuvimos noticia del libro recién publicado por Beatriz Rojas, Las instituciones de gobierno y la élite local. Aguascalientes del siglo XVII hasta la independencia, El Colegio de Michoacán/Instituto Mora, México, 1998. El texto, entre otros asuntos, estudia con detalle la actividad del cabildo y su relación con las élites de poder de la región.
} 


\section{I) LA ESTRUCTURA POLÍTICA ANTERIOR A LA ORDENANZA \\ DE INTENDENTES Y EL REFORMISMO BORBÓNICO}

Para poder valorar cual fue el impacto que tuvo en el gobierno local la aplicación de la Ordenanza de Intendentes en 1786 es importante describir, aunque sea de manera breve, la estructura política que en el nivel local y provincial existía en la Nueva España durante el siglo XVII, sobre todo en lo referente a la relación entre el ayuntamiento, el alcalde ordinario o corregidor y el gobernador.

Es conocida la gran importancia que los ayuntamientos tenían en la administración de los recursos económicos de las villas y ciudades españolas; sus atribuciones les permitían controlar el tránsito de personas y mercancías, mantener el aprovisionamiento de las ciudades, impartir justicia y cuidar el orden público. ${ }^{2}$

No es de extrañar, entonces, que la Corona haya tratado de mantener cierto control sobre estos cuerpos, para lo cual recurrió principalmente a los alcaldes mayores, funcionarios distritales que debían ejercer un estrecho control sobre los ayuntamientos mediante la presidencia del cabildo, la supervisión y autorización de eleccio-

durante la época colonial; aunque no tuvimos oportunidad de incorporar las aportaciones del libro cabe mencionar que coincide en algunos aspectos con las conclusiones a las que arribamos en el presente estudio, sobre todo en lo referente a la relación establecida entre ayuntamientos y subdelegados a fines del siglo XVIII.

${ }^{2}$ Horst Pietschmann, Las reformas borbónicas y el sistema de intendencias en Nueva España. Un estudio político administrativo, Fondo de Cultura Económica, México, 1996, pp. 81, 98, 109 y "Consideraciones en torno al protoliberalismo, reformas borbónicas y revolución. La Nueva España en el último tercio del siglo XVIII", en Historia Mexicana, Volumen XLI, Número 2, [162], octubre-diciembre de 1991, pp. 179. Pietschmann resalta la sujeción de los ayuntamientos, en contraste con Pedro Pérez Herrero, que señala que los cabildos recurrían a medios como las "súplicas", "quejas" o "informaciones" para oponerse a la injerencia del gobierno central. Ver: "El México borbónico: ¿Un ‘éxito’ fracasado?”, en Josefina Zoraida Vázquez, (coordinadora), Interpretaciones del siglo XVIII mexicano. El impacto de las reformas borbónicas, Editorial Nueva Imagen, México, 1992, pp. 142, 143. 
nes -con voto de calidad en caso de empate- y el derecho de veto sobre las resoluciones tomadas por el cuerpo municipal. ${ }^{3}$

Por encima de los alcaldes mayores y corregidores se encontraban los gobernadores, funcionarios encargados del gobierno y administración de las provincias o reinos. Sus funciones principales eran las de impartir justicia, cuidar de la seguridad de su provincia y, en algunos casos, nombrar alcaldes mayores y corregidores. $\mathrm{Al}$ parecer la autoridad de estos funcionarios no era muy importante, pues en muchos casos su tarea se limitaba a una "supervisión de alto nivel" y a emitir normas de carácter general que las autoridades de la provincia, "relativamente independientes", debían obedecer. ${ }^{4}$

El sistema descrito padecía, según la perspectiva de los reformadores borbónicos del siglo XVIII, varios y graves defectos; la centralización que provocaba hacía que el aparato administrativo fuera excesivamente lento e ineficiente; los bajos sueldos de las autoridades distritales fomentaba la corrupción y la extorsión -cuyo mayor ejemplo era la conocida práctica del repartimiento de mercancías-, con el consiguiente descuido de sus tareas de gobierno; no existía una burocracia asalariada y profesional; el sistema fiscal, en manos de particulares, era bastante improductivo, sin mencionar la gran confusión que había con respecto a la división territorial y la sobreposición de facultades y jurisdicciones. Todo esto había, finalmente, fomentado la influencia de las oligarquías locales, en las cuales descansaba el mantenimiento del dominio colonial. Los funcionarios borbónicos, que comenzaron a considerar peligrosa esta influencia que se salía de sus manos, implementarían una serie de reformas destinadas a cambiar esta situación y

${ }^{3}$ Horst Pietschmann, Las reformas borbónicas, pp.93-99. Pedro Pérez Herrero, "El México borbónico", pp.142, 143. José Miranda, Las ideas y las instituciones políticas mexicanas. Primera parte. 1521-1820, unam, México, 1978, pp. 120-127.

${ }^{4}$ Horst Pietschmann, Las reformas borbónicas, pp. 68, 69, 79, 80, 87-93. 
a tomar de nuevo las riendas del gobierno que habían sido soltadas por el régimen de los Habsburgo. ${ }^{5}$

Según la interpretación de Horst Pietschmann, uno de los principales estudiosos del tema, la política reformista acepta una división en tres etapas; la primera etapa, que va de 1765 a 1775, se caracteriza por un ejercer un control más estrecho de las rentas reales, la ampliación del aparato burocrático y la centralización administrativa. Una segunda etapa corre de 1776 a 1786 y tiende más bien a la descentralización, restando facultades a los virreyes y entregando el poder local a los miembros de la élite. La culminación de esta política se dio con la promulgación de la famosa Real Ordenanza para el Establecimiento e Instrucción de Intendentes de ejército y provincia en el reino de la Nueva España, 'en el año de 1786. Finalmente, la tercera y última etapa, que inicia en 1787, conoce una reacción en contra de las medidas descentralizadoras y muchas de las disposiciones de la Ordenanza se modifican o anulan, sobre todo aquellas relacionadas con el nivel local y provincial. ${ }^{6}$

La anterior interpretación, aparte de matizar el grado de ruptura de las reformas borbónicas con el sistema de gobierno anterior, postula también que el impacto de la política reformista fue diferenciado, pues no tuvo la misma influencia en el nivel local que en el nivel de las capitales de provincia o en el gobierno central del virreinato. Tomando en cuenta esta nueva interpretación es que realizaremos el análisis de la Ordenanza de intendentes, resaltando principalmente la cadena de mando formada por ayuntamientos, subdelegados e intendentes y poniendo especial atención en el pa-

"Ibidem, pp. 97, 116, 117, 244. Felipe Castro, Nueva ley y nuevo rey. Reformas borbónicas y rebelión popular en Nueva España, El Colegio de Michoacán-unam, México, 1996, pp. 24-28, 95.

${ }^{6}$ Horst Pietschmann, "Consideraciones en torno al protoliberalismo, reformas borbónicas y revolución. La Nueva España en el último tercio del siglo XVIII", pp. 195-200.

${ }^{7}$ Ibidem, pp. 200, 201. 
pel del subdelegado, sus relaciones con las demás instancias de gobierno y la forma en como sus atribuciones y prerrogativas fueron cambiando con el tiempo, coincidiendo este proceso con la evolución del reformismo borbónico arriba mencionada.

\section{II) LA REAL ORDENANZA PARA EL ESTABLECIMIENTO \\ E INSTRUCCIÓN DE INTENDENTES}

Al principio de la Ordenanza de 1786 el rey de España declaraba que su objetivo al expedir dicha ley era "uniformar el gobierno de los grandes Imperios que Dios me ha confiado, y poner en buen orden, felicidad y defensa mis dilatados dominios". ${ }^{8}$ Están aquí, expresados de manera clara, los dos principales objetivos de la Ordenanza: "uniformar" y poner en "buen orden" significaba racionalizar y mejorar la administración, aumentar el control estatal y establecer una organización burocrática eficiente que buscara un mejor dominio y control de los asuntos fiscales, eliminando los malos manejos y la corrupción. Esto implicaba la creación de nuevos organismos e instituciones, así como una redistribución de las atribuciones hasta ese momento existentes. ${ }^{9}$ A pesar de esto, la Ordenanza no significó una ruptura radical con el antiguo orden administrativo; más bien, el sistema de intendencias se insertó en la organización

\footnotetext{
${ }^{8}$ Real Ordenanza para el Establecimiento e Instrucción de Intendentes de ejército y provincia en el reino de la Nueva España, 1786, (Introducción de Ricardo Rees Jones), unam, México, 1984, pp. 1, 2, edición facsimilar.

${ }^{9}$ Guillermo F. Margadant S., "La ordenanza de intendentes para la Nueva España; ilusiones y logros", en Memoria del IV Congreso de Historia del Derecho Mexicano, Tomo II, Unam, México, 1988, pp. 658. María del Refugio González, "Historia del derecho mexicano", en Introducción al Derecho Mexicano, Tomo I, UNAM, México, 1981, pp. 38, 39. Horst Pietschmann, Las reformas borbónicas, p. 201 y "Consideraciones en torno al protoliberalismo", pp. 176, 185, 186. José Miranda, Las ideas y las instituciones políticas, pp. 191, 198. María Ángeles Gálvez, La conciencia regional en Guadalajara y el gobierno de los intendentes (1786-1800), Unidad Editorial del Gobierno de Jalisco, México, 1996, pp. 5, 6. Real Ordenanza.., pp. XxIv, Xxv.
} 
burocrática vigente hasta entonces, llenando el hueco que había en el nivel provincial, en donde no era evidente una autoridad bien definida que pudiera controlar la administración financiera. ${ }^{10}$

En realidad, los objetivos propuestos estuvieron lejos de alcanzarse y la misma Ordenanza presentaba serias deficiencias internas que la alejaban de los propósitos de uniformidad y racionalidad arriba mencionados, y que hacían que su ejecución fuera muy complicada. Un reflejo de esto puede verse claramente en la distribución de obligaciones y responsabilidades que la Ordenanza establecía para cada una de las autoridades provinciales y locales, asunto del que nos ocuparemos a continuación.

\section{A) Los Intendentes}

Una de las principales innovaciones de la Ordenanza fue la instauración de intendentes, funcionarios provinciales que en cierta manera vinieron a sustituir a los antiguos gobernadores; los intendentes, sin embargo, tenían una autoridad mucho mayor, pues según el artículo séptimo de la legislación estaban a cargo de "los cuatro ramos o causas de Justicia, Policía, Hacienda y Guerra, dándoles para ello [...] toda la jurisdicción y facultades necesarias". ${ }^{11}$ La anterior disposición implicó que el intendente concentrara una gran cantidad de derechos y obligaciones que lo convirtieron en un "gobernador provincial prácticamente omnicompetente", nombrado directamente por el rey y con posibilidades de permanecer en su puesto durante un periodo indefinido de tiempo, aunque, como veremos al

${ }^{10}$ Horst Pietschmann, Las reformas borbónicas, pp. 171, 236, 237, 249. Isabel Gutiérrez, a diferencia de Pietschmann, sostiene que la Ordenanza significó "una ruptura sustancial con el sistema político anteriormente existente". Ver: Isabel Gutiérrez, "El nuevo régimen institucional bajo la ordenanza de intendentes de la Nueva España", en Historia Mexicana, Volumen XXXIX, Número 1, [153], julio-septiembre de 1989, pp. 91, 92.

"Real Ordenanza..., artículo 7. 
detallar sus atribuciones en cada una de las causas, también sufría importantes limitaciones a su autoridad..$^{12}$

\section{La causa de Justicia}

Como Justicias Mayores, los intendentes estaban obligados principalmente a "establecer y mantener la paz en los Pueblos de sus Provincias, evitando que las Justicias de ellos procedan con parcialidad, pasión o venganza", ${ }^{13}$ debían además cuidar que los juicios se tramitaran de manera rápida y sin dilaciones; estaban obligados a mantenerse enterados de los abusos que se cometieran en los pueblos de su territorio y a visitar cada año sus provincias, teniendo la capacidad de hacer comparecer ante ellos a los jueces que descuidaran sus tareas, llamándoles la atención y exhortándolos a que cumplieran con sus obligaciones. ${ }^{14}$ No hay que perder de vista, sin embargo, que en el fondo estas atribuciones eran vagas y muy generales, daban a los intendentes únicamente una función de supervisión general sobre sus provincias y los dejaban supeditados a la autoridad de la Audiencia y el Virrey. De hecho, y aquí es notorio lo poco homogéneo de la jurisdicción del intendente, en la causa de Justicia tenía más autoridad en la capital, gracias a su cargo de corregidor, que en el resto del territorio de la Provincia. ${ }^{15}$

${ }^{12}$ José Miranda, Las ideas y las instituciones políticas, pp. 199. Real Ordenanza..., pp. XXIV, XXV, XXVII. Horst Pietschmann, Las reformas borbónicas, pp. 171, 172, 250, 251 y "Consideraciones en torno al protoliberalismo", pp. 182-184. La frase entre comillas en: David Brading, Mineros y comerciantes en el México borbónico. (17631810), Fondo de Cultura Económica, México, 1975, pp. 97 y 98.

${ }^{13}$ Real Ordenanza ..., artículo 22.

${ }^{14}$ Real Ordenanza..., artículos 23, 24, 26 y 27.

${ }^{15}$ Ricardo Rees Jones, El despotismo ilustrado y los intendentes de la Nueva España, UNAM, México, 1983, pp. 158-160. Guillermo F. Margadant, "La Ordenanza de Intendentes", p. 671. María Ángeles Gálvez, La conciencia regional en Guadalajara, pp. 12, 13. Horst Pietschmann, Las reformas borbónicas, pp. 162, 166, 167, 171, 234,236 y 245. 


\section{La causa de Policía}

Las atribuciones dadas en este ramo al intendente eran también bastante extensas; implicaban básicamente un intento por revitalizar la economía a través de la formación de mapas, informes y relaciones acerca de las condiciones geográficas y económicas para conocer las posibilidades de desarrollo de cada Provincia. Además, el intendente debía cuidar los caminos, fomentar el cultivo de ciertos productos agrícolas (grana, cáñamo, lino, algodón, seda), proteger el desarrollo de la industria, la minería y el comercio, cuidar el abasto de las poblaciones y el estado de los diferentes pósitos y alhóndigas, velar por la circulación correcta de la moneda, ocupándose asimismo de conocer "las inclinaciones, vida y costumbres de los vecinos" para combatir la existencia de vagabundos y mendigos. ${ }^{16} \mathrm{El}$ problema en este caso era similar al de la causa de Justicia, pues no existían determinaciones específicas que indicaran al intendente cómo cumplir con su responsabilidad, ni las posibilidades legales que tenía para hacerlo o los medios de los cuales disponía. ${ }^{17}$

\section{La causa de Hacienda}

El objetivo declarado de la Ordenanza al reglamentar la causa de Hacienda era "mejorar la dirección, administración, recaudación y cuenta y razón de sus ramos" ${ }^{18}$ Para conseguir lo anterior se le otorgó a los intendentes la máxima autoridad en el manejo de las rentas reales; en este caso sus atribuciones eran homogéneas en to-

${ }^{16}$ Real Ordenanza...., artículos 58 a 74. Horst Pietschmann, Las reformas borbónicas, pp.173-175. Ricardo Rees Jones, El despotismo ilustrado, pp. 170-177. María Ángeles Gálvez, La conciencia regional, pp. 12 y 13.

${ }^{17}$ Horst Pietschmann, Las reformas borbónicas, pp. 189-192.

${ }^{18}$ Real Ordenanza..., art. 247. 
da la provincia y se encargaba de la inspección y conocimiento de todas las rentas, así como de la recaudación de tributos; estaba capacitado para impartir justicia en primera instancia y tenía bajo sus órdenes directas a todos los funcionarios encargados de la recaudación de impuestos. Lo relevante en esta caso fue que la dirección-y control del ámbito financiero se trasladaron directamente al intendente, contribuyendo de esta manera a unificar la organización administrativa y posibilitando una intervención más directa sobre este ramo. El intendente, sin embargo, seguía estando supeditado a otras instancias administrativas; en este caso, todas sus decisiones eran apelables ante la Junta Superior de Real Hacienda, la cual podía modificar las decisiones y fallos del intendente. ${ }^{19}$

\section{La causa de Guerra}

En este aspecto, y reflejando también la importancia que se le daba a la administración de las rentas, las atribuciones del intendente se limitaban a cuidar todos los aspectos militares que tuvieran conexión con la Real Hacienda, principalmente aquéllos relacionados con el pago de sueldos, el abastecimiento de las tropas, el control de víveres, la reparación de obras militares y la protección a la población civil de los abusos que pudieran sufrir por parte de las tropas. ${ }^{20}$

La anterior descripción de las atribuciones y obligaciones de los intendentes -en donde no se mencionan aquéllas relacionadas con la administración de la Iglesia-, revela no sólo la gran cantidad de

\footnotetext{
${ }^{19}$ Horst Pietschmann, pp.70, 171, 202, 203, 227, 228. Ricardo Rees Jones, El despotismo ilustrado, pp. 177-186. María Ángeles Gálvez, La conciencia regional, p.14. Real Ordenanza..., los principales artículos sobre las atribuciones de los intendentes en el ramo de hacienda son: 76 a 82,115 a 121, 133 a 138, 142 y 232 a 249.

${ }^{20}$ Real Ordenanza..., artículos 250, 251. Horst Pietschmann, Las reformas borbónicas, pp. 223-225.
} 
responsabilidades de gobierno que pesaban sobre los hombros de estos funcionarios, sino también las limitaciones que la misma Ordenanza les imponía, pues aparte de que los subordinaba a otras instancias de gobierno, no les dio la misma autoridad en las cuatro causas, además de que en varios casos dicha autoridad no era homogénea en todo el territorio de la Provincia. Podría concluirse, pues, que los poderes del intendente no eran lo bastante fuertes ni estaban bien definidos, lo cual les impedía ejercer una autoridad clara sobre sus subordinados. ${ }^{21}$

Esta situación de indefinición y falta de mando se hizo más notoria en el caso de los subdelegados, los cuales quedaron en una posición aún más ambigua que la de los intendentes.

B) Los subdelegados

Como representantes de los intendentes y del poder real en las diferentes localidades, se podría pensar que los subdelegados estaban dotados con facultades suficientes para hacer sentir la influencia del gobierno central en la vida de los pueblos. La Ordenanza de intendentes, sin embargo, no dio a estos funcionarios una autoridad fuerte o incontestable; siendo su objetivo delegar las funciones del gobierno local en las clases altas, la legislación limitó el poder de los subdelegados, los cuales tenían que compartir las atribuciones de gobierno con el ayuntamiento, que, a iravés de los alcaldes ordinarios, tenía una importante injerencia en la administración y manejo de las ciudades y pueblos.

Como se sabe, la Ordenanza contemplaba, para substituir a los antiguos alcaldes mayores y corregidores, la implantación de dos

${ }^{21}$ Guillermo F. Margadant, "La ordenanza de intendentes", p.669. Isabel Gutiérrez, "El nuevo régimen institucional", pp.101-103. Ricardo Rees Jones, El despotismo ilustrado, pp.199-207. Horst Pietschmann, Las reformas borbónicas, pp. 162, 163, 168, 169, 194, 195, 239 у 240. 
tipos de subdelegados; en los pueblos de indios, los subdelegados serían responsables de las cuatro causas de gobierno: justicia, hacienda, policía y guerra; aquí debían administrar justicia y mantener a los naturales en orden, obediencia y civilidad; manejar las tierras y bienes de comunidad, custodiar los caudales y cobrar los tributos. ${ }^{22}$

La situación, sin embargo, era muy diferente en las localidades españolas con ayuntamiento propio; aquí los subdelegados sólo tenían injerencia en los ramos de Hacienda y Guerra, mientras que los alcaldes ordinarios se ocuparían, de manera independiente, de las causas de Justicia y Policía. ${ }^{23}$ En cierto sentido, el conjunto de responsabilidades de los subdelegados adolecía de las mismas debilidades que el de los intendentes: muchas atribuciones limitadas en varios casos a la simple vigilancia y sin especificaciones sobre cómo cumplir con sus tareas. Así, la Ordenanza daba a los subdelegados capacidad para conocer todas las causas y negocios contenciosos relativos al ramo de la Hacienda; debían también tratar de mantener la paz y evitar la parcialidad en la impartición de justicia; substanciar causas de fraude en las rentas de Tabaco, Alcabalas, Pólvora y Naipes; conocer quejas acerca del cobro de impuestos; vigilar el cobro de las alcabalas y el manejo de todos los ramos del erario, revisando los cortes de caja y las cuentas, realizando inventarios anuales y remitiendo toda la información al intendente de la provincia. ${ }^{24}$ Podían, en caso de que así lo dispusiera el intendente, realizar las visitas anuales, estando obligados a dar una información detallada de los arbitrios de cada pueblo y remitiendo a la capital de la intendencia, cada cinco años, las matrículas para el

\footnotetext{
${ }^{22}$ David A. Brading, Mineros y Comerciantes, p. 110. Isabel Gutiérrez, "El nuevo régimen institucional", pp. 111, 112.

${ }^{23}$ Horst Pietschmann, Las reformas borbónicas, pp. 180, 181.

${ }^{24}$ Real Ordenanza..., artículos 22, 79, 80, 121, 232-249. Resulta significativo que la mayoría de estas atribuciones no se especificaban como propias del subdelegado, sino que eran contempladas como inherentes al cargo del intendente, el cual podía delegarlas en dicho funcionario.
} 
cobro de tributos. Finalmente, debían ocuparse de que los puentes y caminos de su jurisdicción estuvieran en buenas condiciones ${ }^{25}$.

Las limitaciones a este conjunto de amplias responsabilidades no dejan de ser significativas; en los pleitos relacionados con la causa de hacienda, por ejemplo, el subdelegado sólo podía preparar los juicios, mas no dictar sentencia, capacidad que era privativa del intendente. ${ }^{26}$.

La relación de los subdelegados con el intendente y con los ayuntamientos era otro elemento que limitaba su autoridad; el problema con el intendente era que su cercanía propiciaba que muchas personas se dirigieran a él para protestar por las medidas del subdelegado cuando estas perjudicaban sus intereses; esto minaba el prestigio de dichos funcionarios, desanimaba a los posibles candidatos a ocupar el puesto y provocaba constantes diferencias y enfrentamientos entre ambas autoridades. ${ }^{27}$

Con respecto al ayuntamiento, las limitaciones del subdelegado eran aún más notorias; aparte de que tenía que compartir la autoridad con los alcaldes ordinarios, el subdelegado no podía presidir el ayuntamiento y, de hecho, las funciones de supervisión y control sobre los cabildos estaban en manos de los intendentes, pues en la mayoría de los casos el subdelegado quedaba limitado a ser un conducto de transmisión de la información sin mucha capacidad de influencia o decisión. Debido a esto, y contrariamente a lo que se piensa acerca del papel de los ayuntamientos, éstos, con la Ordenan-

${ }^{25}$ Ricardo Rees Jones, El despotismo ilustrado, pp. 167. María Ángeles Gálvez, La conciencia regional, pp. 7. Real Ordenanza..., artículos 64 y 122.

${ }^{26}$ Horst Pietschmann, Las reformas borbónicas, pp. 182, 207. Isabel Gutiérrez, "El nuevo régimen institucional", pp. 110 y 111.

${ }^{27}$ Guillermo F. Margadant, "La ordenanza de intendentes, pp. 680. "Instrucción Reservada del Reino de nueva España que el excelentísimo señor virrey Conde de Revillagigedo dio a su sucesor el excelentísimo señor Marqués de Branciforte", en Instrucciones que los virreyes de Nueva España dejaron a sus sucesores..., Tomo II, Imprenta de Ignacio Escalante, México, 1873. pp. 323 y 324. Horst Pietschmann, Las reformas borbonicas, p. 164. 
$z a$ y la supresión de los alcaldes mayores y corregidores, quedaron "liberados del control directo por un funcionario de la Corona" ${ }^{28}$

Hubo además otros problemas provocados por las disposiciones de la Ordenanza que agobiaron constantemente a los subdelegados; podemos aquí mencionar tres: el sueldo, las fianzas y la prohibición de los repartimientos. Los dos primeros están ligados con el asunto del nombramiento. Según la Ordenanza el intendente era libre para nombrar al subdelegado por el tiempo que le pareciera conveniente; los legisladores tenían la intención de que estos nombramientos recayeran en personas de buena posición social, las cuales, se creía, estarían dispuestas a cooperar en la tarea del gobierno local. ${ }^{29}$ Por esta razón a los subdelegados no se les asignó ninguna clase de sueldo fijo y sólo se dispuso que recibirían el 5\% de los tributos recaudados en su jurisdicción. Se les impuso, además, la obligación de presentar fiadores que aseguraran el manejo de las rentas reales. Finalmente no sólo se les prohibió que ejercieran la conocida y lucrativa práctica del repartimiento, sino también el ejercicio del comercio o el simple hecho de poseer una tienda. ${ }^{30}$

Estas disposiciones tuvieron un efecto muy negativo en la marcha del gobierno distrital; los intendentes, por supuesto, sufrieron constantemente por el nombramiento de los subdelegados, pues siempre hubo pocos candidatos dispuestos a ejercer un cargo con tantas responsabilidades y con tan poco sueldo; de esto se quejaba, por ejemplo, el intendente de Valladolid, el cual refería que las subdelegaciones no producían lo necesario para la "decente manutención del subdelegado", sin considerar además que estos funcionarios

${ }^{28}$ David A. Brading, Mineros y comerciantes, pp. 110 y 111 . Horst Pietschmann, Las reformas borbónicas, 182, 183, 247 y "Consideraciones en torno al protoliberalismo", pp. 184.

${ }^{29}$ En cl artículo 77, en donde se prevenía el nombramiento de subdelegados, se enfatizaba que éstos cargos debían recaer en "personas particulares de la mejor nota". Ver: Isabel Gutiérrez, "El nuevo régimen institucional", p. 110.

${ }^{30}$ Horst Pietschmann, Las reformas borbónicas, pp. 180-182, 196, 198. 
...están cargados con otras atenciones que faltaban a los alcaldes mayores, a saber: las certificaciones juradas de reos criminales y estado de sus causas, cada seis meses las noticias de temporales, cosechas o semillas y frutos y sus precios corrientes; las certificaciones sobre imposición o no de multas, las de existencias en las administraciones del Tabaco, las del cumplimiento de la Iglesia, que deben recoger de los párrocos los enteros por tercios de tributos, relaciones juradas de bienes mostrencos, sus pregones y remate [...] y otros varios negocios que se ofrecen a la intendencia. ${ }^{31}$

Por estas razones las personas que se ofrecían para desempeñar el puesto no pertenecían precisamente a los niveles superiores locales y tampoco estaban capacitadas para poder ejercer sus atribuciones; además, en muchos casos se veían obligadas a violar las disposiciones sobre la prohibición del repartimiento y el ejercicio del comercio, en un intento por completar sus precarios ingresos ${ }^{32}$ El conde de Revillagigedo describe vívidamente esta situación y después de señalar la insuficiente retribución de los subdelegados y la clase inadecuada de personas que se presentaban para desempeñar dichos puestos, menciona que

...los subdelegados, que son los jueces ordinarios en sus partidos, ignoran los más el derecho y leyes por donde han de administrar justicia; están fiados a la dirección de sus escribientes o escribanos, y sólo en casos arduos. o cuando hay quien les pague, consultan con Asesor; porque su sueldo, que consiste en el cinco por ciento por la recaudación de tributos, es muy desigual, según a lo que asciende en diversos partidos de la cantidad de éstos. y en donde más, apenas deja para mal comer al Justicia. ${ }^{33}$

Este panorama se completaba con la obligación de otorgar fianza, lo cual, según el juicio crítico del virrey Revillagigedo, hacia que los subdelegados se comprometieran con sus fiadores, viéndo-

${ }^{31}$ Archivo General de la Nación [AGN], Ramo Subdelegados, Volumen 43, fs.12f-14v.

${ }^{32}$ Guillermo F. Margadant, "La ordenanza de intendentes", p. 680. José Miranda, Las ideas y las instituciones políticas, p. 204. Horst Pietschmann, Las reformas borbónicas, p. 289-291.

33 "Instrucción reservada...", pp. 30, 31, 45, 322 y 323. 
se privados para obrar con libertad en los asuntos de administración de justicia en los que se veían implicados. ${ }^{34}$ El mayor problema, sin embargo, era que en muchas ocasiones el subdelegado ni siquiera conseguía personas que quisieran ser sus fiadores, lo que constituía otro obstáculo para su nombramiento, pues sin llenar este requisito no podían tomar posesión de su cargo; enfrentado a este problema el intendente de Guadalajara se vio obligado, en el año de 1793, a mandar subdelegados a que se encargaran de la subdelegación de manera interina y con atribuciones limitadas a la causa de justicia y al cobro de tributos. La corona trató de solucionar este problema ordenando que los subdelegados podrían desempeñar su cargo sin dar fianza durante un periodo de tres meses, tiempo durante el cual sería el intendente el responsable de cualquier desfalco en el cobro de tributos. ${ }^{35}$

Finalmente, los subdelegados, al terminar su periodo de gobierno, quedaban sometidos a un tardado juicio de residencia, que los obligaba a quedarse en el lugar en donde habían desempeñado sus funciones sin poder ocuparse en otros cargos. ${ }^{36}$

Esta situación no duró mucho tiempo, pues tan pronto como empezaron a verse los anteriores inconvenientes producidos por el intento de aplicar los artículos de la Ordenanza, ésta comenzó a sufrir una serie de modificaciones que, ubicándose en la tercera etapa del reformismo borbónico, son un intento por centralizar el poder y fortalecer la débil figura del subdelegado.

Con respecto a sus facultades se decidió, en 1788, no nombrar alcaldes ordinarios en donde no hubieran existido con anterioridad, así como prohibirles la recaudación de tributos, responsabilidad que en adelante sería responsabilidad única de los subdelegados. ${ }^{37}$

${ }^{34}$ Ibidem, pp. 326, 327.

${ }^{35}$ AGN, Ramo Subdelegados, Volumen 32, fs. 1f.-17f. y Volumen 48, fs. 189f-204f.

${ }^{36}$ Guillermo F. Margadant, "La ordenanza de intendentes", p. 681.

${ }^{37}$ David Brading, Mineros y comerciantes, pp. 111 y 112 . AGN, Ramo Historia, Volumen 74, fs. 294f.-v. 
Posteriormente, en marzo de 1793, se dispuso que los subdelegados tuvieran atribuciones en las cuatro causas de gobierno únicamente en las regiones en donde no existiera un ayuntamiento organizado, dejando intacta la situación en los demás poblados; esta medida lo único que provocó fue mayor confusión y más disputas, hasta que finalmente, en marzo de 1797, se dieron instrucciones para que los subdelegados también ejercieran las cuatro causas de gobierno en los poblados en donde hubiera ayuntamiento y en febrero de 1799 se les permitió presidir y no sólo participar en las sesiones de cabildo ${ }^{38}$ Otra serie de reformas limitaron la libertad que tenía el intendente de nombrar subdelegados por el tiempo de su voluntad, pasando esta decisión a manos del virrey y limitando el periodo de gobierno de los subdelegados a cinco años. El proceso inició en octubre de 1788, cuando se decidió transferir al virrey el derecho de confirmar o rechazar los nombramientos de subdelegados hechos por los intendentes; posteriormente, en enero de 1792, se impuso a los subdelegados el periodo de cinco años, se determinó que sólo podían ser suspendidos por el virrey y se transfirió a éste la capacidad de nombrar al subdelegado a partir de una terna propuesta por el intendente, decisión que debería ser aprobada por el rey de España. ${ }^{39}$

La práctica del repartimiento seguía estando tan extendida que terminó por volverse a aprobar en noviembre de 1794, fecha en la

\footnotetext{
${ }^{38}$ David A. Brading, Mineros y comerciantes, pp. 112-114.

${ }^{39}$ Horst Pietschmann, Las reformas borbónicas, pp. 266, 267 y "Dos documentos significativos para la historia del régimen de Intendencias en Nueva España", en Boletín del Archivo General de la Nación, Serie 2, Volumen XII, \# 3 y 4, julio- septiembre y octubre- diciembre de 1971, pp. 405 y 406. María Ángeles Gálvez, La conciencia regional, pp. 39, 40 y 42. José Miranda, Las ideas y las instituciones políticas, p. 204. La intervención del virrey en el nombramiento de subdelegados no era despreciable y aunque en la mayoría de los casos consultados nombraban a los individuos postulados en primer lugar por el intendente, no dejaban de pedir informes sobre la actuación de estos funcionarios, sus antecedentes, periodos de gobiernos, fiadores presentados, etc. Ver: AGN, Ramo Historia, Volumen 159, fs. $26 \mathrm{f}$ y $45 \mathrm{f}-\mathrm{v}$ y Ramo Subdelegados, Volumen 27, fs. $13 \mathrm{f}$.
} 
que se les permitió a los subdelegados vender a los indígenas artículos a crédito y anticiparles dinero sobre las cosechas. ${ }^{40}$

Estas reformas modificaron la naturaleza del subdelegado tal y como había sido concebido en la Ordenanza e implicaron el abandono de la propuesta de ceder el gobierno local a los grupos de élite, optando en cambio por el centralismo y el fortalecimiento del gobierno frente a los ayuntamientos, actor institucional clave en la estructura de gobierno local, cuya situación describiremos a continuación.

\section{C) Los Ayuntamientos}

Como tuvimos oportunidad de mencionar, los ayuntamientos, aún antes del siglo XVIII, tenían una gran cantidad de limitaciones legales a su autonomía; a pesar de esto dicha institución se consolidó como un instrumento a través del cual las oligarquías locales conseguían representación política y defendían sus privilegios y autonomía controlando la administración financiera y de justicia de las ciudades. ${ }^{41}$

Fue la anterior situación la que trató de revertirse durante los primeros años del reformismo borbónico, sobre todo mediante la

\footnotetext{
${ }^{40}$ David A. Brading, Mineros y comerciantes, pp. 122-126. María Ángeles Gálvez, La conciencia regional en Guadalajara, p. 17.

${ }^{41}$ Pedro Santoni, "El cabildo de la ciudad de México ante las reformas militares en Nueva España, 1765-1771", en Historia Mexicana, Volumen XXXıv, Número 3 [135], enero- marzo de 1985, pp. 389, 390. Beatriz Rojas, "Raíz y razón del cabildo novohispano de Aguascalientes", en Ricardo Ávila Palafox, Carlos Martínez Assad, y Jean Meyer, (coordinadores), Las formas y las políticas del dominio agrario. Homenaje a François Chevalier, Editorial Universidad de Guadalajara, México, 1992, pp. 136, 137. C.H. Haring, El imperio hispánico en América, Solar-Hachette, Buenos Aires, 1966, pp. 181-183. Jochen Meissner, "De la representación del reino a la independencia. La lucha constitucional de la élite capitalina de México entre 1716 y 1821", en Historia y Grafía, Número 6, pp. 12, 13. Felipe Castro, Nueva Ley y Nuevo Rey, p. 25.
} 
implementación de medidas administrativas de carácter centraliza dor que intentaban establecer un control más estrecho sobre el manejo de los caudales de propios y arbitrios de los diferentes ayuntamientos de las villas y pueblos de indios de la Nueva España. A este respecto la medida más importante fue el establecimiento, durante la visita de José de Gálvez, de la Contaduría General de Propios y Arbitrios, autoridad especial que se encargaría de fiscalizar las finanzas de las diferentes localidades. Otra medida importante, sobre todo con respecto al ayuntamiento de la ciudad de México, fue la introducción de seis regidores honorarios que, nombrados por el virrey, servirían como contrapeso de los regidores perpetuos que compraban el cargo. El ayuntamiento, por supuesto, protestó y trató de defender la autonomía política y el prestigio que hasta entonces había detentado, haciendo ver las diferencias que empezaban a existir entre la élite residente (compuesta tanto por peninsulares como por criollos) y los nuevos grupos de burócratas españoles que intentaban reforzar el poder del gobierno virreinal. ${ }^{42}$

En las disposiciones de la Ordenanza acerca de los ayuntamientos puede observarse una tensión fundamental; por una parte, como ya vimos al tratar el asunto de los subdelegados, el gobierno renunció a ejercer un control directo sobre las localidades con población blanca al suprimir los cargos de alcalde mayor y corregidor y en su lugar poner a un subdelegado que contara únicamente con atribuciones en dos ramos de gobierno, el cual tenía que compartir la autoridad con los alcaldes ordinarios, que eran elegidos por los regidores; el objetivo era hacer que los grupos privilegiados se comprometieran deci-

${ }^{42}$ Brian R. Hamnett, "Absolutismo ilustrado y crisis multidimensional en el periodo colonial tardío, 1760-1808”, en Josefina Zoraida Vázquez, (coordinadora), Interpretaciones del siglo XVIII Mexicano, pp. 89, 90. Jochen Meissner, "De la representación del reino a la independencia", pp. 21, 22, 25-58. Pedro Santoni, "El cabildo de la ciudad de México", pp. 390, 391 y ss. Pedro Pérez Herrero, "El México Borbónico", pp. 143, 144. Horst Pietschmann, "Consideraciones en torno al protoliberalismo", pp. 185. 
didamente con los asuntos de gobierno y administración local. Esta tendencia, sin embargo, convive contradictoriamente con un renovado esfuerzo por seguir controlando, a través del Intendente y de la Junta Superior de Real Hacienda, todos los aspectos referentes a las finanzas urbanas. ${ }^{43}$

El control sobre la administración municipal se pensaba ejercer a través de tres instancias: el intendente, la Junta Superior de Hacienda y la Junta Municipal. El intendente podía controlar los cabildos y sus finanzas investigando las cargas impuestas a los vecinos, confirmando la elección de alcaldes ordinarios y pidiendo una relación de los propios y arbitrios con que contaba la población, con cuya información elaborarían un reglamento que tendría como objetivo moderar o excluir "las partidas de gastos que les parecieren excesivas, aunque éstas se hallen señaladas y permitidas por ordenanzas o reglamentos antiguos". ${ }^{44}$

En última instancia, el control sobre estos rubros de la administración pertenecía a la Junta Superior de Hacienda, instancia encargada de certificar y autorizar todos los gastos de los cabildos y de decidir acerca de los egresos que se tuvieran que realizar para la construcción de obras públicas y el fomento de la economía y el bienestar general. ${ }^{45}$

Finalmente se establecía que una Junta Municipal, compuesta por el alcalde ordinario más antiguo, dos regidores y el procurador general, se encargaría de todo lo referente a la inversión y manejo de los propios y arbitrios de la ciudad y del arrendamiento de los distintos ramos municipales, poniendo especial cuidado en evitar "las ligas y monopolios que suele haber dentro y fuera de los ayuntamientos". La Junta, en cuyos asuntos no se podrían inmiscuir los

${ }^{43}$ Horst Pietschmann, Las reformas borbónicas, pp. 186-189, 252 y 254.

${ }^{44}$ Real Ordenanza..., artículos 11, 31-33 y 120.

${ }^{45}$ Horst Pietschmann, Las reformas borbónicas, pp. 137, 138. Real Ordenanza..., artículos 28 y 43. 
demás miembros del cabildo, estaba obligada a obedecer las órdenes del intendente "sin excusa ni demora alguna", teniendo la opción de quejarse a la Junta de Real Hacienda si se sentía agraviada por alguna disposición de dicho funcionario. ${ }^{46}$

El objetivo de todas estas disposiciones era no sólo combatir la corrupción y las antiguas prácticas monopólicas, sino, con el aumento de los ingresos que debía resultar, impulsar el desarrollo económico de las localidades mediante la construcción de obras públicas que redundaran en un aumento del bienestar común. ${ }^{47}$

Con respecto a los ayuntamientos, la Ordenanza también sufrió modificaciones posteriores que reflejan la reacción centralista propia de la tercera etapa del reformismo borbónico. Esto se refleja sobre todo en lo referente a los alcaldes ordinarios; como ya hemos mencionado, estos funcionarios tenían atribuciones en los ramos de policía y justicia y podían recaudar tributos; según Revillagigedo los alcaldes no estaban muy extendidos debido precisamente a que "su establecimiento perjudica a los subdelegados, quitándoles la utilidad que les deja el ejercicio de la jurisdicción ordinaria". Los alcaldes, sin embargo, poco a poco fueron perdiendo sus atribuciones a favor de los subdelegados y finalmente, al igual que éstos, acabaron siendo confirmados en su cargo por el virrey. ${ }^{48}$

D) La aplicación de la Ordenanza

Las contradicciones y problemas internos que tenía la Ordenanza de Intendentes se vieron agravados a la hora de intentar su aplicación; de hecho la legislación, tal y como fue expedida, práctica-

\footnotetext{
${ }^{46}$ Real Ordenanza..., artículos 36-39, 49 y 50.

${ }^{47}$ Pedro Pérez Herrero, "El México Borbónico", p. 144. Beatriz Rojas, "Raíz y razón del cabildo", pp. 136 y 137. C.H. Haring, El imperio hispánico, pp. 153 y 154. Horst Pietschmann, Las reformas borbónicas, pp. 184-186.

${ }^{48}$ Real Ordenanza ..., artículos 11, 68 y 129. Guillermo F. Margadant, "La ordenanza de intendentes", p. 673. "Instrucción reservada", pp. 29 y 30.
} 
mente no se puso en marcha, pues muchos de sus artículos fueron derogados o reformados sustancialmente a petición de las mismas autoridades, las cuales los consideraban impracticables.

Los problemas que hubo a la hora de implementar la Ordenanza fueron notorios con los intendentes; estos funcionarios no disfrutaron de legitimidad entre la población; fueron constantemente atacados y desobedecidos; no contaron con la cooperación de la alta burocracia virreinal ni de las autoridades de distrito; sus confusas y amplias atribuciones limitaron su efectividad a la hora de gobernar y poco a poco se les fue quitando autonomía y capacidad de decisión, hasta quedar convertirlos en simples ejecutores de los mandatos del virrey. Así, las visitas anuales no se realizaban, los abusos no pudieron corregirse, los reglamentos de propios y arbitrios raramente se aplicaron y las medidas para fomentar el desarrollo económico nunca pudieron ser llevadas a la práctica. El único campo en donde se notó la acción de los intendentes fue en las capitales de provincia, lugares en los que pudieron mejorar los servicios públicos, construir obras públicas e instaurar medidas de higiene.

Aún esto último tuvieron que hacerlo los intendentes en contra de la oposición de las autoridades locales, principalmente los ayuntamientos, que se negaban a seguir sus instrucciones y sólo cumplían parcialmente con sus obligaciones. De hecho, los intendentes fueron incapaces de extinguir los malos manejos propios de los cabildos, los cuales siguieron funcionando de manera bastante irregular.

Igual de importante que lo anterior fue el hecho de que el intento de aplicar la Ordenanza profundizó las divisiones existentes entre los diferentes grupos de poder novohispanos; esta división va más allá de la dicotomía gachupín-criollo e implica más bien una ruptura entre los nuevos funcionarios ilustrados provenientes de España y la oligarquía criolla que, unida a los grupos peninsulares con intereses económicos en la colonia y a la burocracia tradicional (la 
llamada "élite residente"), se opusieron a los intentos por aplicar las nuevas disposiciones legales. ${ }^{49}$

La forma en que el conflicto por la aplicación de la Ordenanza se dio en Aguascalientes y los rasgos distintivos que presenta dicho caso serán presentados a continuación.

\section{III) Los SUbdelegados DE LA VILLA DE Aguascalientes DURANTE LA ÉPOCA DEL REFORMISMO BORBÓNICO}

Hacia fines del siglo XVIII la subdelegación de Aguascalientes estaba dividida en cuatro partidos: San José de la Isla, San José de Gracia, Asientos y la cabecera, que era la villa de Aguascalientes. Esta última era la población más importante de la jurisdicción y se destacaba por su activo comercio, impulsado sobre todo por su posición geográfica y su cercanía a los reales mineros. Los principales productos que circulaban eran las ropas de Puebla, los géneros y los vinos de Castilla; una muestra de la relevancia de esta actividad la constituye el hecho de que la recaudación en el ramo de alcabalas y tabacos era la segunda más importante de la intendencia de Guadalajara, por debajo tan solo del mineral de Bolaños. La agricultura y la ganadería eran también actividades importantes y de hecho cobraban cada vez mayor relevancia gracias a la continua colonización e incorporación al cultivo de tierras hasta entonces ociosas. Actividad agrícola importante lo era también el cultivo de huertas al interior de la villa, que de hecho era el principal sustento de muchos de sus pobladores.

${ }^{49}$ Brian R. Hamnett, "Absolutismo ilustrado", pp., 68, 78, 79, 93 y 94. Pedro Pérez Herrero, "El México Borbónico", pp. 144 y 145. José Miranda, Las ideas y las instituciones políticas, pp. 204 y 205. María Ángeles Gálvez, La conciencia regional, pp. 20 y 21. Horst Pietschmann, Las reformas borbónicas, pp. 257-265, 268, 274-276, 284-288, 291-294, 306 y "Consideraciones en torno al protoliberalismo", pp. 188, 192 y 193. 
Ni la minería ni las manufacturas tenían un papel destacado; los reales de minas de Asientos y Tepezalá -en donde se explotaban el cobre, el estaño y el magistral-, se encontraban en decadencia y en la villa se encontraban tan solo algunas cuantas curtidurías y obrajes, situación que cambiaría hacia principios de siglo, cuando el español Jacinto López Pimentel estableció una fábrica de paños llamada "El Obraje". ${ }^{50}$

En medio de este contexto es importante resaltar que los españoles constituían uno de los grupos de poder más importantes de la villa, con una gran influencia tanto en la vida política como económica. Según el censo realizado por José Menéndez Valdés había en la villa, hacia 1793, 64 españoles, cantidad que sólo era superada por la capital de la intendencia. Este grupo de españoles controlaba el comercio de la villa y accedía con una gran facilidad a los puestos disponibles en el ayuntamiento. Solían colocarse también como burócratas (administradores de rentas) o militares (lo cual era posible gracias al establecimiento en la población del Regimiento de Dragones Provinciales de la Nueva Galicia). Los peninsulares se integraban rápidamente a la élite residente, casándose con las hijas de las familias criollas acomodadas y desarrollando intereses económicos y políticos en la localidad. Lo anterior apunta hacia la existencia de estrechas ligas entre comerciantes, burócratas y miembros del cabildo, que, no sin estar divididos entre sí, vieron con recelo la llegada de nuevos y extraños funcionarios -los subdelegados- que venían a practicar una vigilancia muchas veces incómoda y molesta para sus intereses. ${ }^{51}$

\footnotetext{
${ }^{50}$ Jesús Gómez Serrano, La creación del estado de Aguascalientes (1786-1857), Consejo Nacional para la Cultura y las Artes, México, 1994, pp. 24-61. Beatriz Rojas, "El cultivo de la vid y la fabricación de chinguirito", en Relaciones, Número 26, primavera de 1986, p. 36. Pedro Pérez Herrero, "El México Borbónico", pp. 131 y 132. Félix María Calleja, "Descripción de la subdelegación de Aguascalientes", en AGN, Ramo Padrones, Volumen 5, fs. If.-6f.

${ }^{51}$ Jesús Gómez Serrano, "Presencia vasca en Aguascalientes durante la época colonial", en Jaime Olveda, (coordinador), Los vascos en el noroccidente de México.
} 
A) Pedro de Herrera Leyva y los problemas con la administración de Tabaco

Pedro de Herrera Leyva fue nombrado subdelegado del partido de Aguascalientes hacia fines de abril de 1789; Leyva era español, natural de Tenerife y se había desempeñado como teniente del Regimiento de Asturias y alcalde mayor del partido de Cimapán entre 1784 y 1788. Llegó a Aguascalientes con 35 años y un hermano, también militar, de 24.52

Su llegada al parecer tuvo un buen efecto en el cabildo local, lo cual se reflejó en la construcción de nuevas obras y los intentos por consolidar los fondos de la villa; el mismo subdelegado se encargó, según sus propias palabras, de construir una caja y una presa para contener las aguas de un arroyo que pasaba junto a la villa inundándola constantemente; esta obra se construyó recurriendo al trabajo forzado de vagos y a la cooperación voluntaria del vecindario de la villa. ${ }^{53}$

Leyva, sin embargo, no dejó de tener problemas con miembros de la burocracia local, en este caso con el administrador de la renta de Tabaco, el español José Manuel Cernadas. El problema se originó el día 2 de agosto de 1792, cuando Antonio Guridi, ejerciendo el cargo de teniente de subdelegado, se presentó en la administración del tabaco con órdenes del intendente de Guadalajara para realizar

Siglos XVI-XVII, El Colegio de Jalisco, México, 1998, pp. 161, 163, 167-169 y "Los vascos en Aguascalientes durante el siglo XVIII", Ponencia presentada en el IV Congreso Internacional: "Los vascos en las regiones de México", Vitoria, Alava, septiembre de 1998, pp. 21, 22, 56, 34-37, 40 y 56. Brian R. Hamnett, "Absolutismo ilustrado", p. 70.

${ }^{52}$ AGN, Ramo Subdelegados, Volumen 7, fs. 373f. y ss. AGN, Padrones, Volumen 5 , fs. $60 \mathrm{v}$.

${ }^{53}$ Beatriz Rojas, "Raíz y razón del cabildo", pp. 136, 137. Pedro de Herrera y Leyva, "Descripción de la villa y subdelegación de Aguascalientes", en Agustín R. González, Historia del Estado de Aguascalientes, Tipografía de V. Villada, México, 1881, pp. 67. 
la revisión mensual que disponía la Ordenanza; Cernadas no dejó de mostrarse extrañado por su presencia, pues aparte de que aseguraba que nadie le había avisado sobre dicha operación, no dejaba de señalar que Guridi no tenía autoridad para realizarla, ya que el subdelegado se encontraba en ese momento presente en la Villa. El enojo de Cernadas aumentó cuando, además de revisar el dinero existente en la caja, Guridi le pidió que abriera "los almacenes para reconocer, recontar y repesar los efectos estancados", a lo cual se negó "por lo laborioso de la operación en un día tan ocupado con las liquidaciones de las cuentas foráneas". En el oficio que el administrador de tabaco mandó a su superior José de Trigo, se quejaba además de "la demasiada autoridad con que se quieren hacer dichas operaciones", las cuales, aparte de ser laboriosas e inútiles, perjudicaban la mercancía. José de Trigo, a su vez, pasó el asunto al intendente José de Ugarte, apoyando la posición de su subordinado acerca de la inutilidad de las revisiones mensuales prevenidas en la Ordenanza. El día 23 de agosto Ugarte comunicó el asunto a las autoridades de la ciudad de México; en su reporte el intendente apoyaba la posición del subdelegado y su teniente, asegurando que él mismo había comisionado a Guridi para que realizara la revisión, además de haber puesto sobre aviso al administrador Cernadas. Este no había sido el único caso de enfrentamiento entre subdelegados y administradores, pues éstos últimos en varios casos se habían negado a que se realizara el corte de caja mensual; la situación se agravó porque hubo subdelegados que intentaron también, sin autorización, revisar las fianzas que habían presentado los administradores para conseguir su empleo. Enterado de esta situación Ugarte advirtió a los subdelegados que no revisaran las fianzas, pues ese asunto era responsabilidad exclusiva de la administración de la renta de tabaco, y que se limitaran al reconocimiento mensual de los caudales. Para salir del paso, Ugarte optó por mantener la revisión mensual hasta nueva orden; ésta fue remitida el 24 de noviembre de 1792 por la Dirección General de la Renta del Tabaco, la 
cual dispuso, primero, que los subdelegados no estarían autorizados para encargar la revisión de las cuentas a terceros a menos que estuvieran ausentes o enfermos; se ordenó también la suspensión de las revisiones mensuales, pues aparte de no ser útiles para llevar un control sobre las cuentas, perjudicaban la mercancía; finalmente se dispuso que en lugar de la anterior operación se remitiera a las oficinas centrales un corte de caja mensual, lo cual implicaba que los subdelegados tendrían una tarea menos por realizar. ${ }^{54}$

Lo anterior viene a reafirmar la impresión resultante del análisis de la Ordenanza acerca de la debilidad del subdelegado ante las autoridades locales y de lo limitado que resultaban sus atribuciones; es interesante comprobar también la reticencia que existía para cumplir con los diversos artículos de la nueva legislación, considerados, en este caso, como inútiles y hasta dañinos para los intereses del gobierno. Finalmente es necesario hacer notar que el choque del subdelegado y su teniente no se da, como pudiera pensarse en primera instancia, contra una institución tradicional como el ayuntamiento, sino con una autoridad de nuevo cuño que estaba en manos de un español de la provincia de Santiago, Manuel Cernadas. Más adelante tendremos oportánidad de ver como vuelve a ocurrir un enfrentamiento similar entre autoridades de reciente implantación. De momento baste con señalar que Herrera Leyva se encontraba, hacia 1793, altamente endeudado, pues en un informe de la Real Hacienda de Guadalajara sobre el estado en que se encontraba la recaudación de tributos, se asentaba que debía la cantidad de 7,396 pesos correspondientes a los años de 1790 y 1791; el problema era grave no sólo porque era el subdelegado que más debía de toda la intendencia de Guadalajara, sino también porque sus fiadores no tenían "el necesario abono" para cubrir el adeudo. ${ }^{55}$

\footnotetext{
${ }^{54}$ AGN, Ramo Oficio de Soria, Volumen 7, Expediente 4, fs. 49v-84v.

${ }^{55}$ AGN, Subdelegados, Volumen 48, fs. 198f.-199f.
} 
B) Juan José Carrillo y Vértiz: la impotencia de un subdelegado

Juan José Carrillo y Vértiz fue nombrado subdelegado de Aguascalientes en substitución de Herrera Leyva en noviembre de 1795 y a diferencia de éste último, tuvo problemas desde el principio de su administración. En septiembre de 1797, por ejemplo, estuvo a punto de ser destituido por disposición del virrey Branciforte, después de que éste se enteró de que a Carrillo no se le había realizado su juicio de residencia al finalizar su periodo como subdelegado de Sayula. El intendente de Guadalajara, Jacobo de Ugarte, que había hecho el nombramiento, argumentó que Carrillo había dado todas las fianzas, que su designación había sido aprobada por el rey y que durante su estancia en Sayula había hecho méritos suficientes y tenido buena conducta. ${ }^{56} \mathrm{El}$ virrey, finalmente, optó por dejar a Carrillo en su puesto, aun a pesar de que éste ya no quería seguir en Aguascalientes y había pedido su traslado a la subdelegación de Lagos, "pues aunque no es de las mejores ventajas, tiene más proporciones que esta en que sirvo". Para fundamentar su petición de traslado, Carrillo pintaba con tintes trágicos su permanencia en la villa:

La infelicidad de mi destino en esta subdelegación, que por sus ningunos emolumentos, no me proporciona el poder sostener en ella a la crecida familia que tengo, ni menos el poder sufragar los gastos para la debida decencia con que debo presentarme en este numeroso y crecido vecindario, me estrecha [a pedir] que se me acomode en destino correspondiente a mi mérito. ${ }^{57}$

Muy diferente era la situación en que se encontraba Jacinto López Pimentel, español proveniente de Sevilla y que se desempeña-

\footnotetext{
${ }^{56}$ Ugarte, por cierto, no mostró preocupación alguna al confesar que, desde el establecimiento de las intendencias, ningún subdelegado había sido sometido al juicio de residencia marcado por la ley.

${ }^{57}$ AGN, Ramo Subdelegados, Volumen 27, fs. 7f-20f.
} 
ba en Aguascalientes, desde marzo de 1789, como administrador de alcabalas.$^{58}$ Como funcionario de la real hacienda, Pimentel gozaba de ciertos privilegios: no podía, por ejemplo, ser aprehendido sin antes dar cuenta a sus superiores y poner a salvo el caudal que manejaba; se le permitía además portar las armas que fueran necesarias para amedrentar a los defraudadores del fisco y obligarlos a pagar y estaba libre de la obligación de desempeñar cargos públicos y concejiles que pudieran distraerlo de sus encargos. ${ }^{59}$

En teoría, Pimentel debía formar parte de esa nueva clase de funcionarios dependientes y asalariados que venían a la Nueva España procedentes de la metrópoli dispuestos a estrechar el control del gobierno sobre la administración local de las finanzas. ${ }^{60} \mathrm{Sin}$ embargo, el administrador de alcabalas rápidamente se integró a la actividad económica local, estableciendo estrechos lazos con la élite residente; así, en 1799 logró casarse con Victoriana Rincón Gallardo, gracias a lo cual se emparentó con la "familia más rica e influyente de la región" y consiguió el capital suficiente para instalar la fábrica de paños El Obraje. ${ }^{61}$

Carrrillo y López Pimentel protagonizarían un fuerte choque en el año de 1797, cuando el subdelegado decidió imponerle una multa de 200 pesos por haber violado un bando real publicado el $12 \mathrm{de}$ febrero que prohibía el cultivo de nuevas viñas en las huertas de la villa de Aguascalientes. Este bando tenía su origen en una causa promovida por el gobierno en 1784 , cuando se descubrió que la gran mayoría de los habitantes de la villa -regidores incluidos-, se dedicaba al próspero giro de la fabricación de chinguirito, bebida

${ }^{58}$ AGN, Ramo Padrones, Volumen 5, fs. 12 y Ramo Historia, Volumen 159, fs. 88v.

${ }^{59}$ Real Ordenanza..., artículos 88 a 93.

${ }^{6}$ David A. Brading, Mineros y comerciantes, pp. 58, 81, 82 y 93. Isabel Olmos, La sociedad mexicana en visperas de la Independencia, (1787-1821), Universidad de Murcia, 1989, pp. 85-87.

${ }^{61}$ Jesús Gómez Serrano, "Los vascos en Aguascalientes", pp. 25 y 26. 
prohibida por las autoridades virreinales. Después de muchas diligencias y un gran escándalo, el asunto fue a parar a la metrópoli, en donde las autoridades se desentendieron del asunto del chinguirito y ordenaron que se limitara el cultivo de viñas en la villa. ${ }^{62}$

El problema entre Pimentel y el subdelegado inició en marzo de.1797, un mes después de la publicación del bando mencionado; en esta ocasión, y después de darse cuenta de que la prohibición del gobierno incluía una multa de 500 pesos para el subdelegado que permitiera el cultivo de nuevas viñas, Carrillo, en un informe dirigido al fiscal de lo civil y al virrey Branciforte, denunciaba el hecho de que el receptor de alcabalas tenía como principal ocupación el plantío de "muchas miles" de cepas en una huerta de su propiedad, violando flagrantemente la cédula real que prohibía dicha actividad; el objetivo de Pimentel, según el subdelegado, era establecer una fábrica de vinos y aguardientes, cosa que, además de estarle prohibido por ser funcionario de hacienda, perjudicaría a muchos individuos pobres de la villa, principalmente a los huerteros, a los cuales dejaría sin agua para sus plantíos. La razón de esto era no sólo que la huerta, de donde habría de salir la materia prima para el establecimiento, necesitaría de una gran cantidad de líquido para subsistir, sino que Pimentel, como mayordomo de propios de la villa, tenía la responsabilidad de repartir el agua entre los dueños de los huertas, por lo cual era de esperarse que sería el primero en apropiarse del agua para favorecer sus propiedades. Finalmente, el subdelegado aseguraba que, al estar tan ocupado en sus negocios, Pimentel descuidaba sus obligaciones como administrador de alcabalas, con notorio perjuicio de la real hacienda.

A pesar de la gravedad de la situación Carrillo no había impuesto el castigo correspondiente a Pimentel -una multa de 200 pesos y la destrucción de las cepas plantadas-; la razón, al parecer, era que

${ }^{62}$ Beatriz Rojas, "El cultivo de la vid", pp. 35 y ss. 
tenía miedo de la reacción del administrador, tal y como lo deja ver en su declaración, en donde argumentaba que no había tomado ninguna medida porque sabía que el "orgullo, altivez y despotismo" propios de Pimentel ocasionarían

...un lance en el cual, después de perderme el respeto al empleo, me había de poner tal vez en la precisión de proceder a su arresto, y a otras actuaciones $[\ldots]$ las cuales siempre habran de incomodar a la superioridad [...] y principalmente si hubiese de proceder a mandarle arrancar los plantíos.

Para evitar esto y posibles perjuicios a la renta de alcabalas, Carrillo decidió comunicar el caso a las autoridades superiores y esperar una resolución

En su respuesta, las autoridades centrales no ocultaron su enojo por la conducta del subdelegado y le hicieron saber "cuan del superior desagrado de V.E. ha sido la vergonzosa timidez con que se ha manejado en cumplimiento de una resolución tan respetable y que si reincide en semejante defecto, será forzoso calificarle por del todo inepto para el desempeño de su encargo". Se le ordenaba, por lo tanto, que "acompañado de un sujeto de notoria probidad", hiciera las averiguaciones correspondientes para comprobar la infracción de López Pimentel y si este resultaba culpable, exigirle los 200 pesos de multa y obligarlo en un término de 24 horas a arrancar las cepas que hubiere plantado después de la promulgación del bando. Carrillo tenía un plazo de 15 días para cumplir con dichas órdenes.

Después de recibir el anterior regaño, el subdelegado, el día 28 de junio de 1797, procedió a nombrar a José Quijano Velarde, capitular más antiguo del ayuntamiento, como "juez acompañado", alegando que los alcaldes ordinarios eran vecinos del comercio de la villa y uno de ellos "estaba comprendido en las diligencias". Carrillo y Quijano hicieron comparecer a tres huerteros, los cuales declararon que, efectivamente, Pimentel había estado plantando una gran cantidad de viñas después del día 12 de febrero, fecha en 
que se publicó el bando real que lo prohibía. Con las declaraciones en la mano, procedieron, ese mismo día, a imponer la multa correspondiente al infractor. Pimentel, por supuesto, se inconformó y el día 30 de junio dirigió una protesta a las autoridades de la capital asegurando que únicamente había trasplantado viñas sembradas desde un año antes y que la denuncia y la multa respondían al odio personal que le tenía el subdelegado, el cual había obrado de mala fe haciendo llegar informes falsos sobre el asunto. Pimentel no perdió oportunidad para asegurar que Carrillo realizaba "operaciones fraudulentas e ilegales", conduciéndose siempre con "pasión" y "codicia" y "atropellando las leyes y los bandos", ocasionando así "la destrucción de esta población". Finalmente pedía que se le regresaran los 200 pesos de multa que había pagado o que, en su defecto, dicha cantidad se mantuviera en depósito dentro de la villa mientras se probaba su inocencia.

Después de enterarse de la inconformidad de Pimentel, Carrillo y Quijano, temiendo que pudiera informar "siniestramente" al virrey, optaron por hacer comparecer a varios huerteros de la villa para que declararan sobre los perjuicios que recibían por la tendencia de Pimentel a aumentar su ya de por sí gran huerta. Así, entre el 3 y el 4 de julio comparecieron 5 personas asegurando que el administrador de alcabalas tenía una huerta de más de 13 mil cepas y que controlaba a su conveniencia el agua de regadío, causándoles con esto un gran daño, pues la mayoría de ellos ya se habían quedado sin agua y perdido sus plantíos por culpa de las prácticas monopólicas del acusado. El subdelegado y Quijano hicieron llegar estas declaraciones a las autoridades de la capital, asegurando que un gran número de huerteros se había presentado espontáneamente a declarar en contra de Pimentel, pero que no los habían interrogado "por no abultar más este expediente, teniendo como tienen por bastante la información recibida". No obstante lo anterior, Carrillo no dudó en acompañar las anteriores declaraciones con un largo alegato en contra del administrador de alcabalas, en donde además 
de repetir sus anteriores acusaciones acerca de las cepas plantadas a destiempo y los perjuicios que ocasionaba a la villa acaparando el agua, añadía otras de bastante interés. El subdelegado hacía énfasis, sobre todo, en la alianza que Pimentel había establecido con las autoridades y vecinos de la villa, por lo cual no le sería difícil, utilizando su "astucia y sagacidad", presentar testigos que declararan a su favor. A este respecto Carrillo hacía alusión a la

...alianza que tiene con todos los individuos que componen este Ayuntamiento, quienes, unos porque son mercaderes y los otros hacenderos, [...] todos ellos necesitan de su favor para sus iguales de alcabalas y aforos de las memorias de ropa que introducen para el surtimiento de sus tiendas; y a más de esto, como con su astucia y labia los tiene embelesados y verdaderamente dominados, y más a los que componen la Junta Municipal.

Pimentel se había valido de estas relaciones para ser nombrado Administrador de...

los propios del ayuntamiento, puesto desde el cual dominaba el reparto del agua y Carrillo no dudaba que utilizaría estas mismas influencias para tratar de salir bien librado de la acusación que le hacía. Otro aspecto que resaltaba el subdelegado de la personalidad de Pimentel era el de sus

...excesos, tanto en [...] perjuicio de la Renta que administra por sus continuos tratos y negociaciones vastas que emprende sin tener caudal propio, y de que es inseparable por su genio codicioso e inclinado a todo género de comercio, como en cuanto a los daños que causa a este común, no sólo en sus intereses, sino aún en la sociedad, paz y tranquilidad, pues con su genio díscolo, trae de continuo perturbados los ánimos y fácilmente los conspira a cualesquiera idea que se propone.

Finalmente Carrillo acusaba a Pimentel de que "tanto en sus concurrencias públicas como privadas, se produce denigrativamente contra el subdelegado", dando mal ejemplo y propiciando que las demás personas "desobedezcan a la Justicia". Un posible reflejo de la influencia a que hacía referencia el subdelegado se 
dejó ver en el mes de septiembre de 1797, fecha en la que el ayuntamiento, en voz de Antonio de Guridi y Jáuregui, denunció las "continuas desavenenciás que está formando don Juan José Carrillo, subdelegado de esta jurisdicción". ".3

Por razones que desconocemos el caso no se resolvió sino hasta 1799; el segundo alegato de la defensa de Pimentel está fechado en marzo de este año y corrió a cargo de su representante personal, Juan María de Cervantes; para estas fechas ya se había realizado un segundo censo de las huertas de la villa, el cual había arrojado un total de 279,898 cepas, cuando el bando de 1797 permitía tan solo 107,396. Este era un signo inequívoco de que no sólo Pimentel había violado la real orden de febrero de 1797 y sería utilizado como argumento de la defensa. En un extenso documento, el representante de Pimentel trata de demostrar su inocencia alegando, en primer lugar, que la denuncia del subdelegado respondía a que Pimentel, como administrador de alcabalas, había rechazado a uno de los fiadores que Carrillo había presentado para poder tomar posesión de su cargo; según la defensa, "esta fidelidad de Pimentel en cumplimiento de su obligación a beneficio de Su Majestad, excitó de tal suerte contra él a Carrillo que desde entonces le ha procurado incomodar por diversos caminos". El enojo del subdelegado aumentó cuando el intendente de Guadalajara le llamó la atención por tratar de intervenir en el manejo de la administración de alcabalas. Por otra parte se aseguraba que los testigos que había mandado a llamar Carrillo para que declararan en contra de Pimentel eran gente de la plebe, lo cual las volvía poco confiables, además de que sus declaraciones eran contradictorias y no demostraban de manera indudable que Pimentel hubiera violado el bando de 1797. Además no era probable que la huerta de Pimentel fuera a dejar a las demás sin agua, pues el administrador tenía su propia noria y

6.3 Jesús Gómez Serrano, "Los vascos en Aguascalientes", p. 39. 
acueductos por medio de los cuales se abastecía del líquido suficiente, teniendo la bondad de ceder gratuitamente al vecindario el líquido sobrante. Se criticaba también el hecho de que el nuevo censo había sido realizado por personas ignorantes, por lo que no era confiable. Después de esto venían los argumentos de carácter económico: el cultivo de viñas no afectaba la fábrica y venta de vinos españoles, pues la mayoría de las uvas se destinaban para hacer dulce o se vendían como fruta; en cambio su destrucción afectaría profundamente a la villa, la cual

subsiste de este ramo de agricultura [...] y estrecharlo sería arruinar un lugar tan considerable con perjuicio de tantas familias y del Estado, a quien es conveniente no sólo mantener sino aumentar la población de este reino, proteger y fomentar la industria, y el recomendable ramo de la Agricultura, trayendo por otra parte gran provecho a la real hacienda mantener el número actual de cepas, porque de ellas [...] percibe Su Majestad sus derechos de alcabalas, pagan diezmos y primicias en que también interesa el soberano. y la pensión de propios en beneficio del público.

Se negaba también la acusación acerca de que Pimentel descuidara sus ocupaciones como administrador, pues para él la huerta era solo "un objeto de recreo, diversión y desahogo", además de que no había nada que objetar ante el hecho de que bajo su administración había aumentado la recaudación de este ramo.

$\mathrm{Al}$ parecer los anteriores argumentos fueron suficientes para que, el 13 de agosto de 1799, el oidor fiscal de Guadalajara ordenara la devolución a Pimentel de los 200 pesos de multa, argumentando que ésta se había impuesto sin que la infracción fuera totalmente comprobada. ${ }^{6+}$

Carrillo y Vértiz terminó su periodo de gobierno en el año de 1799 y todavía tuvo que defenderse de una demanda interpuesta contra

${ }^{6}$ Todas las diligencias en que nos basamos para hacer el anterior relato están en: AGN, Ramo Industria y Comercio, Volumen 17, expediente 5, fs. 235f.-292v. 
él por un comerciante de Sayula, el cual aseguraba haberle prestado 2,000 pesos, cantidad que Carrillo se negaba a pagarle; así, el subdelegado terminó sus funciones de gobierno tal y como las había -empezado: quejándose de que no tenía el dinero necesario para mantener a su familia, que en la villa de Aguascalientes nadie le quería prestar dinero y que no percibía "ningunos emolumentos de este infelicísimo empleo que sirvo, costeado de mi propio bolsillo". ${ }^{65}$

El anterior suceso resulta interesante por varias razones; en primer lugar da evidencia para seguir comprobando la posición de debilidad en que se encontraba el subdelegado ante los aparatos y grupos de poder locales; las prevenciones de Carrillo para multar a Pimentel por temor a lo que éste pudiera hacer para defenderse son bastante ilustrativas de dicha debilidad. La anterior situación no se debía únicamente a la personalidad del administrador, sino también a las estrechas relaciones establecidas con la élite local; esto apunta otra vez al hecho de que eran precisamente los españoles venidos a ejercer un control más estrecho sobre las finanzas locales, los que acababan aliándose con los grupos de poder de la localidad y utilizando su puesto para provecho propio. Pensamos que este es un ejemplo claro de cómo la élite residente (compuesta indistintamente por criollos y peninsulares que dominaban las instituciones de gobierno antiguas -como el ayuntamiento- y de reciente creación -como la Junta Municipal y las administración de alcabalas-) evitaba la vigilancia y control que, a través de los subdelegados, intentaba ejercer el gobierno virreinal. El contraste con los objetivos originales de la Ordenanza resulta entonces evidente; no había necesidad de delegar las tareas de gobierno en manos de los notables locales dándoles el cargo de subdelegados, tal y como lo había planteado en un primer momento la misma legislación; los notables locales ya tenían el control del gobierno y no veían la ne-

${ }^{65}$ AGN, Ramo Donativos y Préstamos, Volumen 14, fs. 21 -22f. 
cesidad de ejercer un cargo por lo demás pesado, mal remunerado y sin prestigio ni legitimidad. Preferían, en todo caso, seguir en el ayuntamiento, plataforma desde la cual fueron incorporando a los burócratas recién llegados a la red de intereses de la localidad: en medio de esta situación los subdelegados no tardaron en ser vistos más bien como agentes extraños que, desde una posición notoriamente débil, trataban de ejercer una vigilancia por lo demás incómoda para la red de intereses locales. La posición de los subdelegados como elementos externos a las localidades que intentaban gobernar se hace más notoria si analizamos la política que seguían los intendentes al nombrar a estos funcionarios; este aspecto será el que trataremos a continuación.

C) José María Cardona y el nombramiento de subdelegados

En agosto de 1809, José María Cardona se dirigió al virrey Lizana pidiendo que lo nombraran subdelegado de Lagos o Aguascalientes, pues tenía una orden del rey en la cual se le concedía este cargo; en su escrito Cardona se quejó de que venía pidiendo dicha colocación desde el año de 1796, cuando se dirigió al intendente Jacobo Ugarte para que se diera cumplimiento a la real orden; al parecer Cardona no fue del agrado del intendente, el cual le dijo que se dirigiera al virrey Branciforte para arreglar su asunto; como era de esperarse el virrey regresó a Cardona con el intendente indicándole que para poder ser subdelegado debía ser postulado previamente en una terna y recomendándole que no pidiera Aguascalientes como destino, pues para estas fechas se desempeñaba como subdelegado del partido Carrillo y Vértiz. Nada pasó y llegó el año de 1809 sin que Cardona encontrara colocación. Cuando en este año volvió a insistir no dejó de mencionar los cargos que había desempeñado anteriormente: regidor perpetuo del ayuntamiento durante once años; alcalde ordinario durante cuatro; síndico procurador y tesorero de los fondos del cabildo y, finalmente, diputado y comisiona- 
do para la compra de maíz durante la crisis agrícola de 1786. Durante esta última comisión tuvo que pagar los viajes de su propio bolsillo, gastos que se unieron a los realizados "para solemnizar la proclamación y jura de nuestro amado rey el señor Don Carlos Cuarto". Todo esto agotó los fondos de Cardona, el cual se vio obligado a renunciar al cargo de regidor y a buscar una colocación que le proporcionara los ingresos suficientes para mantener a su "dilatada familia". Por esta razón y como para conseguir cualquier puesto había que realizar excesivos gastos y dar "extraordinarios obsequios que no compensan los emolumentos que producen dichos destinos", volvió a insistir en el cumplimiento de la orden del rey. ${ }^{66}$

Para estas fechas se desempeñaba como intendente de Guadalajara Roque Abarca, el cual se caracterizaba por tener una política bastante definida para nombrar subdelegados: no debían ser naturales ni vecinos del partido que fueran a gobernar ni tampoco debían tener minas ni haciendas en su jurisdicción. Es notorio además que la mayoría de las personas propuestas por Abarca en primer lugar para ocupar el cargo de subdelegados tenían una carrera previa en la burocracia virreinal. Un ejemplo típico es el de Nicolás Garavito, subdelegado del partido de Huauchinango, el cual con anterioridad había sido cabo del resguardo de alcabalas, guarda de la renta del tabaco, teniente provincial del real de la Acordada y desempeñado el fielato de Tequila. ${ }^{67}$

El mismo Roque Abarca, en un informe hecho llegar al virrey en el año de 1809, confesaba que en el caso de nombramiento de subdelegados y en igualdad de méritos, prefería a los pobres por encima de los ricos, tratando además de nombrar subdelegados interinos en los partidos que fueran quedando vacantes pues

\footnotetext{
${ }^{66}$ AGN, Ramo Subdelegados, Volumen 27, fs. 256f.-26lf.

${ }^{67}$ Algunos nombramientos de Roque Abarca en: AGN, Ramo Subdelegados, Volumen 43, fs. 235f.-245v, 346f-377f.
} 
...más vale que se nombre interinos para observarles la conducta, que exponernos a los gravísimos daños que podríamos experimentar si por desgracia se nombrase a un hombre imbuido en ideas contrarias a la causa de Dios y del perseguido Fernando Séptimo, nuestro legítimo soberano. ${ }^{68}$

En estas condiciones, las posibilidades de que Cardona fuera nombrado subdelegado eran mínimas, pues tenía todos los requisitos que Abarca estaba evitando al nombrar estos funcionarios: era miembro declarado de la élite local y no tenía experiencia en la burocracia virreinal. Lo anterior es importante porque significa un cambio radical con respecto a lo que se buscaba al expedir la Ordenanza en 1786; cuando se formó esta ley se quería que los subdelegados fueran notables de la localidad que habrían de gobernar; años después, el intendente de Guadalajara nombraba como subdelegados a personas pobres ajenas al partido al que eran asignados, buscando, posiblemente, que los diferentes subdelegados dependieran más del intendente que de los intereses de las localidades.

D) Aguascalientes: un ayuntamiento sin subdelegado

El cabildo de la villa de Aguascalientes funcionó sin subdelegados entre 1799 y 1803 y entre 1805 y 1809; durante este tiempo el único subdelegado del que tenemos noticia es José Joaquín Maciel, que desempeñó el cargo de 1803 a 1805. ${ }^{69}$ Lo anterior es importante porque constituye una evidencia acerca de la preeminencia que durante estos años tuvo el gobierno local y de la libertad de acción de que gozó el ayuntamiento en este tiempo.

El ayuntamiento estaba compuesto tanto por españoles como por criollos; estas personas se concebían como miembros de una élite y, como tales, estaban en una constante búsqueda de privilegios y dignidades. A diferencia del subdelegado, que en muchas ocasio-

\footnotetext{
${ }^{68}$ AGN, Ramo Subdelegados, Volumen 19, fs. 192f-193f.

${ }^{68}$ AGN, Ramo Subdelegados, Volumen 16, fs. 20f. y Volumen 27, fs. 256f-26lf.
} 
nes no tenía el dinero suficiente para vestirse de manera apropiada, los regidores tuvieron la prerrogativa, a partir de 1791, de vestir uniformes compuestos de casaca, calzón azul, chupa y collarín blanco rodeado de un galón de oro. ${ }^{70} \mathrm{El}$ cabildo, además, detentaba el título de "ilustre", sus miembros eran recibidos con agua bendita en la iglesia y tenían el derecho de bancas cubiertas en las funciones de tabla ${ }^{71}$. En 1801 los regidores decidieron que, aparte de los anteriores privilegios, al cabildo debía hacérsele el obsequio de "repique y órgano a la entrada y salida [del templo], darle la paz y finalmente le faltan las mazas, sin las cuales sale como incompleto, deslucido o desairado". ${ }^{72}$

Confiados en que estos privilegios se les concederían sin mayor trámite, los miembros del cabildo elevaron su petición a las autoridades de la capital, no sin antes mencionar los donativos que se habían dado para la causa de la guerra y los 4,500 pesos que habían producido al real erario la venta de las seis plazas de regidores, enfatizando las ventajas que tendría para la Real Hacienda el conceder los privilegios pedidos, pues de esa manera, los cargos serían codiciados y demandados por los "vecinos más honrados y pudientes".

Grande fue la sorpresa de los regidores cuando supieron, en noviembre de 1803, que el gobierno sólo había concedido el uso de mazas, especificando además que, en adelante, el ayuntamiento se abstuviera de utilizar el título de "ilustre"; los miembros del cabildo, por supuesto, no dejaron de manifestar su "dolor y sentimien-

\footnotetext{
${ }^{70}$ AGN, Ramo General de Parte, Volumen 72, fs. 39f.

${ }^{71}$ Pedro de Herrera Leyva, "Descripción de la villa y subdelegación de Aguascalientes", pp. 61, 62.

${ }^{72}$ Estos detalles, que pueden parecer poco importantes eran muy significativos en una sociedad como la colonial, en donde el traje y la vestimenta correspondían a una identidad social y predominaba el formalismo y el gran celo por la imagen presentada. Ver: Alberro Solange, Del gachupín al criollo. O de cómo los españoles dejaron de serlo, El Colegio de México, México, 1992, pp. 175 y 221.
} 
to" por la anterior resolución, pues alegaban que ayuntamientos como los de León y Lagos, que administraban villas con menor tradición o importancia comercial, disfrutaban de los privilegios que a ellos se les habían negado; lo que más les dolió, sin embargo, fue que se les prohibiera utilizar el apelativo de "ilustre", pues, con esta disposición, lejos de adelantar como era su intención, iban para atrás, ya que perderían la "posesión, costumbre y práctica en que estamos de que a este Cabildo se le diga y trate de Ilustre, como que se compone de sujetos de lustre, nobleza y distinción". Finalmente lo único que se les permitió a los regidores, a partir de 1805 , fue el uso de mazas, aprobándose un gasto de 200 pesos para su construcción. ${ }^{73}$

Había ocasiones, sin embargo, en que los regidores se ocupaban de cosas más trascendentes para el bienestar público que la construcción de mazas o la utilización de uniformes; en 1809, por ejemplo, y ante la inminente escasez de maíz por la falta de lluvias, los regidores expidieron una serie de medidas destinadas a asegurar el abasto de la villa; así, se prohibió la extracción de granos de la jurisdicción, se mandó a hacer un recuento para saber cuales eran las existencias con las que se contaba y se acordó una multa de 100 pesos para quien comprara maíz dentro de los límites de la subdelegación; finalmente se pidió permiso a la Junta Superior de Real Hacienda para conseguir un préstamo de 20 mil pesos con el cual comprar el maíz necesario para mantener abastecida a la población. ${ }^{74}$

Estamos, pues, ante una realidad compleja; tenemos por una parte a un cabildo en constante búsqueda de privilegios y que actúa con una gran libertad gracias a la ausencia de un subdelegado; a pesar de esto, no tenía la capacidad financiera suficiente para hacer frente a una crisis agrícola y tenía que pedir permiso hasta pa-

\footnotetext{
${ }^{73} \mathrm{AGN}$, Ramo Intendencias, Volumen 71, expedientes 9 y 10.

${ }^{74}$ AGN, Ramo Intendencias, Volumen 44, expediente 16.
} 
ra endeudarse. La sujeción, como mencionábamos con anterioridad, no se daba con respecto a la autoridad distrital sino a la central, representada principalmente en el virrey y la Junta Superior de Real Hacienda.

E) La incorporación a Zacatecas: un ataque a la autonomía local

En 1803 la subdelegación de Aguascalientes, junto con la de Juchipila, fue separada de la intendencia de Guadalajara e incorporada a la de Zacatecas; esta medida significó la culminación de los esfuerzos que los intendentes de Zacatecas venían realizando desde la década de 1780, cuando empezaron a sostener que la incorporación de Aguascalientes facilitaría la recaudación de impuestos y acabaría con la especulación de semillas, práctica constante de los agricultores de Aguascalientes que perjudicaba el abasto de las minas existentes en aquella intendencia. ${ }^{75}$

$\mathrm{Al}$ parecer una de las primeras medidas del gobierno de Zacatecas fue poner a un subdelegado en el partido de Aguascalientes -el ya mencionado José Joaquín Masciel-, el cual se desempeñó en su cargo entre los años de 1803 y 1805. Al igual que sus antecesores, Masciel tuvo problemas con la élite local; el choque, en este caso, sucedió con el alcalde ordinario Mateo Gutiérrez de Velasco, el cual, acostumbrado a desempeñar su cargo sin la presencia de un subdelegado, tenía la pretensión de extender sus facultades a todo el territorio de la subdelegación. Masciel, por supuesto, se negó a que Gutiérrez ejerciera tales facultades y, para evitar que las cosas se complicaran más, y temiendo una competencia entre él y el alcalde, decidió recurrir al intendente pidiéndole que declarara que el ejercicio de la alcaldía ordinaria debía restringirse a los límites de la población de la villa de Aguascalientes. El intendente de Za-

${ }^{75}$ Jesús Gómez Serrano, La creación del estado de Aguascalientes, pp. 64-75. 
catecas apoyó la propuesta de Masciel y ordenó que el alcalde dejara de excederse en cuanto a la extensión de su jurisdicción. ${ }^{76}$

Posteriormente, en el año de 1809, el subdelegado interino Rafael Chávez tuvo la oportunidad de conocer a Jacinto López Pimentel, que en esta ocasión se negó a que se le hiciera una revisión completa de los caudales y los "enteros" que manejaba en la administración de alcabalas argumentando que "pasa inmediatamente a la dirección general las certificaciones que recibe, y que las facultades del subdelegado son [...] limitadas al puro acto del corte o reconocimiento de las existencias". 77

Las evidencias disponibles encajan con lo que dice Jesús Gómez acerca de que, acostumbrada a actuar e manera independiente, la élite aguascalentense vio con malos ojos su incorporación a Zacatecas, pues estaba habituada, como tuvimos oportunidad de comprobar, a actuar con amplios márgenes de autonomía, los cuales, seguramente, se fueron estrechando conforme la intendencia de Zacatecas iba consolidando su dominio sobre la subdelegación recién incorporada. ${ }^{78}$

\section{CONCLUSIONES}

Nuestro trabajo sustenta dos conclusiones generales. El primer aspecto que nos interesa resaltar se refiere a las reformas borbónicas en general y a la Ordenanza de Intendentes en particular; a este respecto creemos que lo más relevante es el hecho de que las reformas borbónicas, contrariamente a lo que a veces se piensa, no tuvieron siempre los mismos objetivos ni se valieron de los mismos medios para conseguirlos. Los intentos por centralizar el gobierno se mezclan y confunden con los esfuerzos por descentralizar la ad-

\footnotetext{
${ }^{76}$ Ibidem, pp. 78-80.

${ }^{77}$ AGN, Ramo Intendencias, Volumen 72, expediente 33.

${ }^{78}$ Jesús Gómez, La creación del estado de Aguascalientes, pp. 77.
} 
ministración y aún los mismos objetivos de homogeneizar las divisiones territoriales y las facultades de las autoridades tuvieron importantes excepciones contempladas y fomentadas por los mismos reformadores.

La Ordenanza no es en este caso sino un reflejo de dichas contradicciones; esto tuvimos oportunidad de observarlo al analizar las atribuciones de los intendentes y subdelegados; al principio estos funcionarios poseían facultades generales y muy ambiguas que contribuyeron a debilitar su autoridad y dificultar su acción de gobierno; las posteriores modificaciones a la Ordenanza no solucionaron este problema $y$, en un intento por centralizar el gobierno, restaron facultades a los intendentes y trataron de fortalecer a los subdelegados, todo esto a favor de la autoridad virreinal. Mientras esto sucedía los ayuntamientos estaban también en medio de una situación hasta cierto punto paradójica, pues gozando de cierta libertad de acción al no estar sujetos a una fuerte autoridad distrital, se encontraban limitados en sus finanzas por la intervención del intendente y de las autoridades fiscales de la capital.

$\mathrm{El}$ anterior panorama se complica aún más si empezamos a tomar en cuenta la aplicación concreta de la Ordenanza en un caso particular -la subdelegación de Aguascalientes a fines del siglo XVIII-. Aunque los casos documentados son fragmentarios y no otorgan un panorama general de la situación, podrían dar pie a hipótesis de carácter provisional. En este segundo aspecto de las conclusiones es necesario resaltar cómo el análisis del caso de Aguascalientes en cierta manera confirma la posición de debilidad en que estuvo el subdelegado durante esta época, aún después que se le dio injerencia en las cuatro causas de gobierno. Lo novedoso del asunto es que los choques del subdelegado fueron no sólo ni principalmente con el ayuntamiento, sino sobre todo con las autoridades burocráticas establecidas por los mismos reformadores borbónicos años antes. Así pudimos observar como los administradores de alcabalas o del estanco de tabaco se mostraban reacios a permitir 
que el subdelegado fiscalizara sus actividades y llegaban a establecer estrechas relaciones con la élite local, la cual, compuesta indistintamente por españoles y criollos, tuvo la capacidad suficiente para incorporar a estos nuevos funcionarios a su red de intereses, con beneficio para ambas partes. Esta élite residente utilizó el ayuntamiento para seguir controlando los asuntos administrativos de la villa y oponerse a los intentos de vigilancia y fiscalización realizados por el gobierno virreinal; esto se ve reflejado en el hecho de que al menos durante 9 años el partido de Aguascalientes no contó con subdelegado, siendo sus funciones desempeñadas por el alcalde ordinario, funcionario electo por los mismo regidores. Acostumbrada a esta clase de autonomía, no es de extrañar que la élite local haya visto con malos ojos la incorporación de Aguascalientes a Zacatecas, lo cual implicaba un reforzamiento del control por parte de autoridades externas; este sentimiento duraría varios años y, en última instancia, sería el fermento que permitiría la separación de Aguascalientes de Zacatecas y su creación como estado independiente; en esta caso, estaríamos de nuevo ante un proceso que, culminando a mediados del siglo XIX, tendría su origen en los últimos años del siglo pasado. 


$$
\text { . }
$$

